\title{
A Role for Coercive Force in the Theory of Global Justice?
}

\author{
Endre Begby, Simon Fraser University \\ endre.begby@gmail.com
}

\section{Introductory}

Global Justice theory is characterized by an uncompromising commitment to the universal validity of a wide range of social, economic, and political rights. These rights are held by individual human beings irrespective of the material, social, or political conditions they happen to live under. Importantly, these rights also correlate with bystander obligations. In the words of Martha Nussbaum, a leading theorist of the Global Justice movement, "the whole world is under a collective obligation to secure the capabilities to all the world's citizens" (Nussbaum 2011: 167). ${ }^{1}$ This essay raises questions about the sorts of means that we can deploy as we seek to discharge these obligations. In particular, it asks whether there can be a place within Global Justice theory for third-party employment of coercive force to vindicate these rights.

At first blush, it would appear that Global Justice theory harbors a deeply ingrained skepticism concerning the employment of coercive force. Global Justice theory emerges out of a broadly post-colonial political discourse: concerns about lending unwitting justification to neocolonialist power schemes figure prominently in discussions of the role of coercive force in vindicating rights. Western powers' willingness to reserve coercive measures as policy tools is part of a problem of global justice rather than a solution. ${ }^{2}$

It seems fair to say, then, that the first wave of philosophical writings on global justice displays a broadly pacifist political orientation. This is particularly evident in its near exclusive focus on institutional reform, whereby we seek to develop a framework for dealing with pervasive, structural injustices - the prototypical causes of conflict - by peaceful means. In this, Global Justice theory is clearly an intellectual heir to the program outlined by Immanuel Kant in

\footnotetext{
${ }^{1}$ See Nussbaum 2011: 62-68 for an account of the relation between capabilities and rights.

2 See Miller 2003 for such a view.
} 
Perpetual Peace (1795), which seeks to render war obsolete by addressing its root causes via institutional reform. ${ }^{3}$

One could argue, however, that it is easy to maintain a pacifist orientation of this sort when one is focused on distinctively non-territorial international institutions, as first wave Global Justice theory almost exclusively has been. For illustration, consider a (partial) list of Thomas Pogge's many seminal contributions to Global Justice theory, such as the global resources dividend (Pogge 1998), his critique of international borrowing and resource privileges (Pogge 2005), and his proposal for restructuring medical patents law (Pogge 2009). To my mind, these proposals add up to what might just be the most important body of work in any area of contemporary philosophy. But this should not obscure the fact that all these proposals are targeted on reforming institutions to which coercive force was never a relevant policy tool in the first place. In these sorts of cases, foreswearing any role for coercive force comes at very little cost.

But as the sweep of Global Justice theory has more recently expanded from a focus on economic rights primarily to also include a wide range of social and political rights (e.g., Caney 2005; Brock 2009; Nussbaum 2011), this dismissive attitude toward the use of coercive force will be significantly harder to maintain. As we have seen, Global Justice theory is rooted in a conception of the universality of an expansive set of individual human rights. Under our current political reality, these agenda-setting rights are largely if not exclusively managed by the domestic institutions of individual states. And for the most part, they are massively mismanaged by those institutions. This is a standing affront to the principles of global justice, and the question arises as to what can be done about it, if anything can.

\section{The Coercion Continuum and the Threshold Conception of Just Cause}

In light of these facts, it is tempting to think that current Global Justice theory entails a possibly very expansive mandate for coercive third-party intervention. If, for instance, the theory affirms a global right to live under reasonable legal institutions and representative forms of government,

\footnotetext{
${ }^{3}$ Selections reprinted in Reichberg, Syse, and Begby 2006: 519-538. See also Begby, Reichberg, and Syse 2012a: 321-323 for commentary and historical context.
} 
then we are under a collective obligation to secure these rights to everyone everywhere. The world being what it is, it would be naïve to think that we could ever discharge that obligation without the use of coercion.

However, most Global Justice theorists recoil from this implication. The point is usually put in terms of what I will call a threshold conception of just cause: coercive measures are justified only in a very small range of cases which meet a certain threshold of injustice and suffering. The threshold is usually set at cases of genocide, massacre, enslavement, and ethnic cleansing, i.e., the cases that are nowadays usually discussed under the heading of "Humanitarian Intervention." In cases that fall below this threshold, there can be no role for coercive force. Thus, for instance, Global Justice theory will evidently not sanction the use of coercive force to secure women's right to vote. Infractions of such rights, unjust as they may be, are just not grave enough to warrant the use of coercive means, even in cases where such means would be available and expedient.

In my view, this threshold conception of just cause for intervention is problematic in its own right, but leaves Global Justice theory, in particular, facing a serious explanatory deficit. If systematic and pervasive rights-violations do not provide third-parties with just cause for employing the means necessary to stop them, what is meant by saying that we are under a standing obligation to secure these rights? We can again turn to Nussbaum to articulate the underlying suspicion. Addressing the importance of state interventions to prevent domestic abuse of women, she writes that "all entitlements involve an affirmative task for government: it must actively support capabilities, not just fail to set up obstacles. In the absence of action, rights are mere words on paper" (Nussbaum 2011: 65). Granted, there are significant differences between the enforcement of rights in the domestic and international settings (not the least of which is the absence of effective governmental institutions in the latter). But none of these differences entail that foreigners do not have the same rights as we do, and that where these rights are violated, the "whole world is under a collective obligation" to restore them. Why, then, should we not 
conclude that the Global Justice program of universal social and political rights reduces to "mere words on paper" if it precludes the use such means as might be necessary to enforce them? $?^{4}$

I believe this explanatory deficit must be addressed if Global Justice theory is to sustain its status as a cogent and comprehensive account of rights and obligations in the international sphere. This paper will outline a remedy for the problem, one that would that would allow us to assert that systematic and sustained abuses of the full range of social and political rights can provide just cause for intervention, at the same time as we honor the post-colonial political sensibilities that have led most Global Justice theorists to seek a more restrictive conception of just cause.

Two themes, in particular, will run through much of my subsequent discussion. The first theme is that coercive measures occupy a broad spectrum, on which we can distinguish, for instance, state-issued condemnation or reprimands at one end, economic sanctions somewhere in the middle, and full-blown military intervention at the other end. ${ }^{5}$ Call this, the Coercion Continuum. However, when we look closer at discussions of the place of coercion in contemporary Global Justice theory, we find a virtually exclusive focus on military intervention. To my mind, this narrow focus significantly biases the debate. If we keep the full range of the Coercion Continuum in mind as we approach the question, we might receive strikingly different policy recommendations, or so I will argue.

The second theme proceeds from a familiar insight from Just War theory, namely that just cause is a necessary but not a sufficient condition for the use of force. In other words, one can have just cause without having an all-things-considered justification. All-things-considered justification obtains only when further prudential constraints are met: the decision to deploy force must be taken by agents vested with the right authority and guided by the right intention; the effort must have a reasonable hope of success and must be proportional to the wrong it seeks

\footnotetext{
${ }^{4}$ The situation is reminiscent of how liberal critics of the 2003 invasion of Iraq were frequently made to answer charges of moral hypocrisy, of being 'all talk' and 'no action' when push comes to shove. For a sampling of such criticism, see the essays collected in Cushman 2005. I will return to the Iraq case in section 3.3 of this essay.

${ }^{5}$ See, for instance, Chatterjee and Scheid (2003: 1-2), who cast the net extremely widely: "many types of actions, besides military ones, can be coercive and may count as "interventions," including: espionage; discriminatory economic policies such as trade sanctions and embargoes; selective foreign aid (that is, granting or denying foreign aid); financial aid to subversive movements within a foreign country; the arming, supplying and training of rebel forces; and so on."
} 
to put right; finally, it must constitute a last resort. ${ }^{6}$ The important point, for our purposes, is that Just War theory fully recognizes, as any political theory should, that one may find oneself in the tragic predicament of having just cause in virtue of another's wrongdoing, all the while possessing no just means of vindicating that cause.

These two themes coalesce in the following way: what a particular situation in some country can give rise to - be it genocide, the political exclusion of women, or the harassment of sexual minorities - is not just cause for any particular means of intervention - be it military, economic, diplomatic. Instead, what it gives rise to is just cause for intervention, full stop. Quite simply, it is no part of the logic of the just cause criterion that it be relativized to particular means in this way. Which particular means of intervention, if any, are appropriate to the situation can only be determined by recourse to the further prudential criteria. Against this background, two important points emerge: (1) the different means which are plotted along the Coercion Continuum will perform very differently with regard to the prudential criteria, even as they all answer to the same condition of just cause. (Clearly, for instance, diplomatic sanctions may be proportional in a case where economic sanctions are not). (2) We may well find ourselves in situations where none of the coercive means at our disposal will satisfy the prudential constraints. These may indeed be quite common. In such cases, we will have just cause, but lack all-things-considered justification. But even in such cases, it is vitally important that we continue to recognize that there is indeed just cause. The fact that there is nothing to be done (at the current time) about a particular situation does not mean that we should not recognize that a wrong has been committed.

A central diagnostic claim of this paper, then, can be summed up as follows: many leading Global Justice theorists have been guilty of attempting to adjust their conception of just cause to fit their intuitive verdicts on which cases warrant coercive intervention, all things considered. This is simply a mistake. The mistake is compounded when they restrict their discussion of coercive force to its most drastic instantiation, namely military intervention. Rather, Global Justice theory should acknowledge that systematic and sustained violations the full range of social and political rights can provide just cause for the employment of coercive force. This does not entail a blanket justification for hegemonic imposition, because there is real

\footnotetext{
${ }^{6}$ For a fuller account, see Begby, Reichberg, and Syse 2012b.
} 
constraining power in the prudential criteria, correctly applied. If intuition scoffs at the idea that it could ever be right to employ military means to vindicate women's suffrage, for instance, this is not because such action would lack just cause, but rather because it would hardly ever be prudent.

\section{The Problem of Intervention in Recent Global Justice Theory}

The contemporary consensus on the justifiability of coercive third-party intervention is formed in large part by Michael Walzer's discussion in Just and Unjust Wars (Walzer 1977), further reinforced by John Rawls's discussion in The Law of Peoples (Rawls 1999). In rough outline, the consensus recognizes that preventable human suffering comes in degrees, but maintains that only situations which go above a certain threshold could justify coercive intervention from the outside. $^{7}$ Following Walzer, this threshold is usually set to at genocide, massacre, enslavement, and possibly massive forced displacement. ${ }^{8}$

It is natural to ask, of course, why less grievous situations could not also justify coercive force, if such means are available and expedient. Walzer's answer makes appeal to what I will call a two-tiered conception of political legitimacy: institutions and policies which would be clearly illegitimate by our (liberal-democratic) standards may nonetheless be legitimate by their domestic standards. On this supposition, there is a strong presumption against foreign intervention to prevent lesser degrees of political injustice because such interventions would undermine state sovereignty and thereby communal autonomy. Walzer writes: "A state is selfdetermining even if its citizens struggle and fail to establish free institutions, but it has been deprived of self-determination if such institutions are established by an intrusive neighbor" (Walzer 1977: 87). Thus, it is not the case that "intervention is justified whenever revolution is; for revolutionary activity is an exercise in self-determination, while foreign interference denies to a people those political capacities that only such exercise can bring" (Walzer 1977: 89). Nonetheless, the prohibition on intervention is not absolute, because some cases are so grave that one must "doubt the very existence of a political community to which the idea of self-

\footnotetext{
${ }^{7}$ See Altman and Wellman 2009: 96-99 for a critical examination of the consensus view.

${ }^{8}$ See Walzer 1977: 90; Walzer 1980. For a fuller analysis, see Begby 2003.
} 
determination might apply" (Walzer 1977: 101). Clear examples include genocide, massacre, and enslavement.

As we shall see, many leading Global Justice theorists offer policy recommendations regarding coercive intervention which are materially equivalent to those of Walzer. They agree that the justifiability of coercive intervention is tied to a threshold, and they agree, to a reasonable approximation, about where the threshold should be set. However, it should be clear that Global Justice theorists do not endorse the two-tiered conception of political legitimacy which Walzer (and Rawls) believe supports this conclusion. In Walzer and Rawls, this two-tiered conception of political legitimacy betrays a distinctive collectivist streak, starkly illustrated by Walzer with the claim that international politics must be guided by a strongly entrenched default assumption of a "fit" between a people and its government, even when that government engages in large scale political repression. ${ }^{9}$ Rawls's view is somewhat less stark, but remarkable nonetheless: he holds that a state can qualify as a "people" despite very significant, sometimes compounded inequalities among individual citizens. ${ }^{10}$

Such arguments, one must suppose, sit poorly with the individualist predilections of Global Justice theory: states have no moral standing in their own right, except as they act competently and diligently to protect and uphold a wide range of individual rights. ${ }^{11}$ Without appeal to a two-tiered conception of political legitimacy, how can Global Justice theory justify the threshold conception of just cause? We will now turn to seeing how leading figures in the Global Justice movement attempt to develop this theme.

\subsection{Nussbaum}

As we have seen, Martha Nussbaum asserts that "the whole world is under a collective obligation to secure the capabilities to all the world's citizens" (Nussbaum 2011: 167). Surveying the state

\footnotetext{
${ }^{9}$ On this, see Walzer 1980. For criticism, see Luban 1980a, 1980b.

${ }^{10}$ See Begby 2010: 56-57 for more detailed analysis of the kinds of compounded inequalities permitted within Rawls's theory.

${ }^{11}$ More generally, the two-tiered conception of political legitimacy is clearly a philosophical cousin of the two-stage model of the social contract as applied to international distributive justice, which the Global Justice movement has emphatically rejected since the beginning. For seminal arguments against Rawls's implementation of this two-stage model, see Beitz 1979 and Pogge 1989.
} 
of the world, we can only conclude we are currently egregiously remiss in discharging our obligations. Whether we focus on economic, social, or political dimensions of deprivation and injustice, the vast majority of the world's citizens are currently very far from realizing their capabilities. So it is natural to ask, what means may we employ to improve on the current situation?

As it turns out, there are substantial, principled limits to what we can do. In particular, Nussbaum's scheme maintains a staunch preference for persuasion over force, and leaves little room for coercive measures. This is, of course, a good thing: but it does not answer the question of what we can do when attempts to persuade have run their course. Here, Nussbaum advocates a restrictive stance:

I hold (following standard accounts of humanitarian intervention) that military and economic sanctions are justified only in certain very grave circumstances involving traditionally recognized crimes against humanity, such as genocide. Even when there are such crimes, it is often a strategic mistake to intervene, particularly if the nation is a democratic one that can be persuaded to repudiate the heinous acts. (Nussbaum 2011: $111-112)^{12}$

This restrictive stance is motivated by the need to deflect a "colonialism critique," i.e., the claim that Global Justice theory can end up serving neo-colonial aims, by way of providing grounds for intervention. Similar concerns lay behind Walzer's and Rawls's thinking. But where they appeal to the two-tiered conception of political legitimacy, no such move is available to a Global Justice theorist. What, then, can Nussbaum do to secure her conclusion?

\footnotetext{
${ }^{12}$ I confess I am puzzled by Nussbaum's stance here. Presumably what we want when we are discussing the possibility of intervention is to put an end to these atrocities, not to "repudiate" them. Against that background, what she says about the 2002 conflict in Gujarat strikes me as troubling in the extreme. Acknowledging the genocidal character of the violence, but noting that India is "a nation with a thriving democracy," she writes that "so long as there is a decent chance that democracy itself can address the issue - as by now, seven years later, it has to a large degree done - it would be totally mistaken to intervene forcibly" (Nussbaum 2011: 112). To my mind, the fact that genocidal violence may have political and legal repercussions seven years down the line cannot on its own constitute an argument against intervening to stop the violence as it unfolds.
} 
She offers two sorts of justifications. One appeals to a "strong separation between issues of justification and issues of implementation" (Nussbaum 2011: 111). On her view, the Capabilities Approach provides grounds for justified moral judgment, but offers limited counsel for how to implement these moral judgments. The other appeals to the value of state sovereignty, which, of course, is particularly robust in democracies. Intervention, then, is morally problematic because it involves a violation of state sovereignty: "national sovereignty is sufficiently important that military intervention is never justified when a nation has a decent minimum of democratic legitimacy" (Nussbaum 2011: 121).

I believe both these justifications are problematic. Starting with the first, there is, of course, nothing wrong with asserting a distinction between questions of justification and questions about implementation. Indeed, the distinction is categorical and fundamental. But it is doubtful that this distinction will help Nussbaum bridge the explanatory gap that her theory incurs by way of its restrictive stance on coercive intervention. Some writers, including Allen Buchanan (2006) and John Tasioulas (2009), have offered reasons to doubt that there is any intrinsic conceptual connection between assertions about rights and justifications for intervention, such that whenever an agent A's right to $\mathbf{R}$ is undermined by another's wrongdoing, $\mathbf{A}$ then has a claim on bystander $\mathbf{B}$ to help secure $\mathbf{R}$. But even this (quite controversial) ${ }^{13}$ stance offers little support for Nussbaum's view, for the simple reason her argument would concern not the relation between rights and interventions, but the connection between obligations and interventions. She writes: "Entitlements, on my view, are correlative with duties: if people have entitlements, then there is a duty to secure them, even it is difficult to say to whom the duty belongs" (Nussbaum 2011: 167). It is hard to see how a $\boldsymbol{B}$ 's duty to secure $\boldsymbol{A}$ 's right to $\boldsymbol{R}$ would not entail at least a pro tanto right for $\mathbf{B}$ to intervene whenever $\mathbf{A}$ 's right to $\mathbf{R}$ is frustrated by another's wrongdoing.

Nussbaum's second argument appeals to the value of state sovereignty. This appeal faces critical questions right away, even if we restrict our discussion to democracies: to whom are these institutions valuable? Democratic institutions are compatible with several degrees of political disenfranchisement, not to mention capability failures on other fronts. Our obligations are owed to the people who suffer capability failure under such institutions. And it is simply not clear why

\footnotetext{
${ }^{13}$ See, for instance, Hinsch and Stepanians (2006) and Raz (2010) for the case against.
} 
we should assume, by default, that the integrity of the political institutions they live under have intrinsic value to them (as opposed, say, merely to the privileged set within their state). Here it seems that Nussbaum's view comes very close to reaffirming the two-tiered conception of political legitimacy that we found objectionable in Walzer and Rawls.

These arguments can be strengthened along two interrelated axes. First, whereas Nussbaum's analysis suggests a sharp threshold for just cause, the value of democratic institutions is clearly a matter of degree: the degree of value will be sensitive to the degree of disenfranchisement or capability failure suffered by the people to whom our obligations are owed. Second, the degree to which the value of democratic institutions constrain justified intervention must clearly be sensitive to the kind of intervention under consideration: since different means of coercive intervention entail different degrees of imposition on domestic political institutions, there is scant sense to be made of the claim that "the value" of democratic institutions impose a strict threshold on just cause for interventions.

This brings me to my final point: it is simply a mistake to appeal to the value of state sovereignty in determining what sorts of situations may provide just cause for intervention, if that is what Nussbaum means to do. This is not to say the value of such institutions should carry no weight in our moral deliberations. Rather, the point is that whatever we take the value of such institutions to be, that value should factor on the prudential side of our moral calculations. They will be relevant to our all-things-considered judgments about the use of coercive force in particular cases (though differently relevant in different cases), not because they constrain just cause, but rather because they figure in the proportionality calculus. For instance, in determining whether a particular intervention would be justified all-things-considered, we must assess whether the damages it would likely incur could be proportional to the good that it reasonably aims to achieve. Here we must ask, among other things, about the value that the political institutions whose shape or direction we would be seeking to change have to the people who would be affected by the intervention. But it should be clear that such questions can only be asked subsequently to determining that there was indeed just cause for intervention in the first place. 


\subsection{Brock}

Like Nussbaum, Gillian Brock believes that Global Justice theory must be sensitive to a "tension between respecting sovereignty and responding to the plight of the needy" (Brock 2009: 173). Moreover, like Nussbaum, she advocates a threshold conception of just cause: "[n]ot all basic needs and liberties warrant intervention, only some do and under certain circumstances" (Brock 2009: 172). However, her approach to justifying this stance differs markedly from Nussbaum's. ${ }^{14}$

Brock approaches the matter by way of an adaptation of Rawls's original position to international affairs: you are to imagine that you have been "randomly selected to be a decisionmaking delegate to a global conference, which will establish a fair framework for interactions and relations among the world's inhabitants" (Brock 2009: 174). While the usual veil-ofignorance constraints apply, delegates are presumed to be aware of certain general facts about our world and its history. This background knowledge, Brock believes, generates a powerful incentive among delegates to avoid two sorts of situations:

The first is one in which basic threats to life, liberty, and the prospects of a minimally decent life are widespread; for instance, a situation in which genocide, 'ethnic cleansing,' large-scale killing, torture, or violence persists, and the government is either actively engaged in causing the situation of fails to take action to remedy it. The second is one in which powerful states (or other actors) are able to interfere in people's lives and do so for their own purposes (though they might disingenuously claim to be acting for the benefit of those they affect.) People would not want the rhetoric of humanitarian intervention to provide a mechanism for powerful states to muscle their way in to other countries for their own reasons. (Brock 2009: 176).

With these constraints in mind, the delegates turn to assessing when, if at all, military intervention can be justified. Upon deliberation, they determine that "large-scale loss of life,

\footnotetext{
${ }^{14}$ Brock also mentions (2009: 173) a second tension, which arises from the deployment of violent means to promote peace. But it should be clear that this tension does not arise, or at least does not arise in the same way, for other means along the coercion continuum.
} 
'ethnic cleansing,' torture, rape, displacement of people from their homes and livelihoods," are cases where "it would be reasonable to suggest the just cause threshold has been reached" (Brock 2009: 178). Debating whether the threshold might be set lower, so as to encompass violations of a fuller range of the rights asserted by Global Justice theory, Brock warns that that "[b]ecause the delegates have legitimate fears about abuse, they might understandably be cautious about sanctioning the use of force in cases where the level of harm is not grave and substantial" (Brock 2009: 178). She adds that these fears might also compel them to introduce yet further constraints in addition to the constraints built into the just cause threshold itself. These are the familiar prudential criteria of the jus ad bellum mentioned above, such as right intention, proportionality, last resort, and reasonable hope of success.

At this point, however, it seems that something has gone wrong. The fear of hegemonic abuse is entirely legitimate. But it would be pointless to attempt to encode these constraints twice, which is what this proposal in effect would be doing; first, in terms of a high threshold for just cause, and, second, in terms of further prudential constraints. Constraining the abuse of power is precisely in part what prudential criteria such as right intention and proportionality are there to do. It is simply a mistake to attempt to also delimit the range of just cause on those same grounds. Differently put, there might be other grounds for insisting on a high threshold for just cause. But following the logic of Just War theory, these grounds cannot be ones that make essential appeal to prudential criteria, since these prudential criteria can only be cogently applied after the question of just cause has already been settled. Consequently, Brock's delegates should be advised that they are free to assert that the full range of Global Justice rights can provide just cause for intervention, without fear of providing unwitting justification for hegemony.

\subsection{Tan}

This last point is explicitly recognized by some contributors to Global Justice theory. Kok-Chor Tan is among these. In a recent article, he acknowledges the widespread concern that liberal cosmopolitanism, due to its expansive and demanding political platform, is "a conception of global justice with strong interventionist tendencies" (Tan 2010: 155). He argues, however, that this fear is unfounded: 
the stricter conditions of state legitimacy under cosmopolitanism do not mean that justification for intervention is easier to come by. Even if the failure to attain legitimacy satisfies the just cause condition, it does not follow that immediately that the other conditions of permissibility are also satisfied. Recall the other conditions noted above, that of "last resort" and "proportionality." Even if a society's failure to respect the liberal democratic rights of its citizens constitutes a just cause for intervention, it has to be shown that intervention is the last option in the sense that feasible non-military and political and economic means have been attempted unsuccessfully. (Tan 2010: 170)

These observations confirm one of the main messages of this essay: Global Justice theory can and should assert that violations of the whole range of political rights may provide just cause for intervention. Specifically, it is a mistake to attempt to constrain overzealous interventionism by imposing a high threshold for just cause. The factors that one would appeal to in order to boost the threshold already figure as constraining factors in the form of the further prudential criteria.

Having made these observations, however, Tan inexplicably goes on to introduce a high threshold for intervention after all, all but confirming the Walzerian stance echoed by Nussbaum and Brock. He writes:

a cosmopolitan can hold that a state that fails to meet liberal standards fails the legitimacy test, but failure of legitimacy in itself need not even meet the just cause condition. It is the kind of failure of illegitimacy that is relevant. [...] it is only [with] illegitimacy of certain kinds, that involving grave violations of human rights, that the just cause criterion for military intervention is met. [...] To be more precise then, one could say that a forfeiture of legitimacy does not by itself give just cause for any thirdparty state to intervene. There is no just cause because the failure of compliance, in the case of a decent society, is not egregious or so extreme as to shock the conscience of mankind. (Tan 2010: 172) 
What could account for this apparent about face? One possibility is that Tan is here paying the price for considering coercion exclusively under the guise of military intervention. In his discussion, the other means along the coercion continuum figure only as benchmarks for satisfying the last resort condition. Accordingly, when Tan is pressed on the question of whether a particular instance of political injustice, though not so egregious as to "shock the conscience of mankind," could provide just cause, he automatically understands this as a question of whether it could provide justification for military intervention. But that is simply the wrong question: the correct question is what provides just cause for intervention tout court, not what provides just cause for any particular means of intervention. As I have stressed, which particular means of intervention is appropriate to a given situation, if indeed any, should not be raised and answered in terms of just cause.

This conflation wreaks havoc on Tan's discussion of the 2003 invasion of Iraq. Here we must clearly distinguish at least four questions: (i) Was there just cause for intervention? (ii) Would intervention have been justified all-things-considered? (iii) Was there all-thingsconsidered justification for military intervention? (iv) Was there all-things-considered justification for the US-led military intervention that actually took place?

Tan's discussion does not adequately distinguish between these questions. As noted above, he specifically reads the question of just cause as a question about just cause for military intervention. Thus, he allows that "Saddam's regime was clearly tyrannical and illegitimate" but goes on to ask: "does it follow from this claim of illegitimacy and tyranny that military intervention is warranted?" (Tan 2010: 173). The question of "warrant" here is plainly ambiguous between just cause and all-things-considered justification. The fact that the example is raised in the context of discussing thresholds for just cause would suggest that he has in mind the former. However, what he goes on to say suggests that he has in mind the latter: is the intervention likely to do more harm than good? What are the alternatives? Tan concludes: "Considerations of these questions do not immediately suggest the right to intervene. On the contrary, they suggest the impermissibility and the counter-productiveness of the intervention" (ibid.). 
This is fine, and most commentators would agree that the 2003 invasion was not justified, all things considered. ${ }^{15}$ But still, any attempt to deny that the track record of Saddam's regime provided just cause for intervention would land Global Justice theory with a serious credibility deficit. In fact, I would hazard to guess that most commentators again would agree that there were multiple and overdetermined just causes for intervention. What does not follow from an assertion of just cause, however, is which mode of intervention, if any, would be justified allthings-considered. But Tan's virtually exclusive focus on one end of the coercion continuum military intervention - prevents this distinction from coming properly into focus.

To ease these problems, Tan sometimes appears to suggest (cf. 2010: 174) that even in the absence of just cause, we are always free to deploy non-military modes of coercion, such as diplomatic pressure or economic sanctions. This is not an uncommon view. However, it cannot be made consistent with the general principles of Global Justice theory. Economic sanctions, no less than military means, constitute an attempt at directing the policies of a target state from outside. They, no less than military means, can serve the ends of hegemonic power. And so, they no less than military means, should be constrained both by just cause and by the further prudential criteria. Moreover, we must bear in mind that while we typically count military means as constituting the extreme end of the coercion continuum, even military intervention can come in degrees, and in many instances, protracted economic sanctions can be as damaging as limited use of military force (and far less discriminate). ${ }^{16}$ Thus, there is every reason within Global Justice theory to hold that even non-military means of coercive sanction are not within the discretionary power of each state, but must meet a test for just cause. The just cause condition, as I have argued, contains no reference to particular means of intervention. Instead, which means, if any, are appropriate to the situation can only be settled by recourse to the further prudential criteria.

\footnotetext{
${ }^{15}$ See Begby 2012 for a detailed account.

${ }^{16}$ See ICISS 2001: 29-30 for critical remarks on the use of blanket economic sanctions, as well as Ali and Shah 2000 and Global Policy Forum 2002 for estimations of damages wrought by the sanctions regime on Iraq.
} 


\subsection{Caney}

These points are ably made by Simon Caney, whose discussion of intervention comes closest to affirming the outlook of this paper. He specifically notes that "coercion can take different forms and we therefore have no reason to limit intervention to military modes of coercion alone" (Caney 2005: 229). Moreover, his discussion of the justifiability of intervention (broadly understood) fully observes the distinction between having just cause and having all-thingsconsidered justification. Thus, where other Global Justice theorists tend to advocate a high threshold for just cause, Caney asserts that just cause obtains whenever "a political regime violates people's human rights (where this includes rights to a decent standard of living as well as rights against torture, murder, unjust imprisonment or enslavement)" (Caney 2005: 248). By contrast, determining which interventionary means are appropriate to a particular situation requires that we consult further prudential criteria. Accordingly, these criteria are understood as coming into action independently of and subsequent to clarifying the just cause criterion. Caney writes, very much in line with my prefatory remarks above, that

intervention may involve non-military types of coercion including embargoes or sanctions or monitoring elections. All of these are acts that coerce another political regime or the members of another political regime. It is important, however, to note their diversity because some objections to intervention may have force against some types of interventionary behaviour but not others. (Caney 2005: 231)

This constitutes a considerable advance on the discussions we find in Nussbaum, Brock, and Tan. But even Caney's discussion is not as clear as one would like. Caney is worried that some will find his conception of just cause to be too permissive. Starting from the observation that "not all human rights are of equal moral significance," he acknowledges that someone might argue the just cause criterion "should be recast to 'fundamental' human rights. Otherwise we might be forced to conclude that intervention is required for rather 'insignificant' human rights" (Caney 2005: 261n37). Among 'insignificant' human rights, I presume the objector is referring to Caney's inclusion of a right to a "decent standard of living;" certainly, my own inclusion of a 
right to adequate political representation and protection from harassment would fall in the same category. Accordingly, it is plain to see that the hypothetical objector is trying to sway us to reintroduce a threshold conception of just cause.

Caney offers an indirect response: the objection is not fatal, because "[i]nterventions always incur considerable costs and it would therefore not be justified to intervene for minor rights violations. Furthermore, any legitimate authority is highly unlikely to justify intervention except for fundamental rights violations" (ibid.).

This response spoils the point. It is conceivably true that there is always some cost incurred by intervention. But as Caney's own discussion should make amply clear, these costs will vary significantly with the means adopted. Thus, it is simply false to say that the cost of intervention will always rule out all-things-considered justification for coercive force in the case of 'non-fundamental' human rights. Instead, the objection calls for a direct response, and the resources for articulating that response are already present in Caney's theoretical framework. The objection commits the mistake of assuming that assertions about just cause translate directly into assertions about the justifiability of intervention in particular cases. Accordingly, we would be mistaken to restrict our conception of just cause to fit our all-things-considered judgments about when intervention is justified. Thus, even as we can concede that the range of rights asserted under Global Justice theory can be ranked with respect to how 'fundamental' they are to the lives of individual lives, the objection provides no reason for retracting the claim that all these rights can provide just cause for coercive intervention.

\section{A Role for Coercive Force in the Theory of Global Justice}

Perhaps the cleanest way for Global Justice theory to meet these problems is to return to the distinction between justification and implementation (Nussbaum 2011: 111), and to apply it without compromise and across the board. Global Justice theory, then, offers grounds for the justification of a wide range of rights-claims, but has nothing to say about the implementation or enforcement of such rights. I believe few could take much joy from the resulting account. The promise of a philosophically anchored platform for political change is simply vanished. 
Nussbaum's own remark about how rights-claims reduce to mere "words on paper" if not backed up by action seems most apt.

A different strategy, widely favored by Global Justice theorists, is to make room for a limited role for coercive force: with respect to particularly egregious violations of a narrow set of fundamental rights (to deploy terminology from the above discussion), the distinction between justification and implementation breaks down, and we now have just cause for coercive intervention. In cases of violations of non-fundamental rights, by contrast, there is no such just cause.

This strategy essentially entails cleaving the set of rights claimed under the theory into two; the set of rights whose violation is sanctionable and constitutes just cause, and the set of rights whose violation is neither. With this move, Global Justice theory becomes virtually indistinguishable from the sort of view we find in Rawls 1999, according to which the members of the second set are "rights" only in an attenuated sense. They are not properly thought of in terms of universally valid claims at all. Instead, they are more aptly described as "liberal aspirations" (Rawls 1999: 80n23): only liberal regimes are sanctionable for failing to implement these rights, simply because they are part of our political culture and tradition, though not theirs. We may, of course, hope that they could become universally honored. But it would be parochial of us to frame policies aimed at realizing that hope. This cannot, I submit, be a satisfactory result for Global Justice theory. ${ }^{17}$ For example, gendered or racist patterns of political exclusion are not faults of liberal democracies alone. They are, or should be, sanctionable wherever they occur, irrespective of the history or character of the political culture in question.

The remaining strategy is to hold that while these are all rights in the true and proper sense, only a select few are sufficiently fundamental to the lives of individual people as to warrant coercive intervention from outside. This is the strategy which has provided my focal point in this essay. This strategy becomes untenable as soon the distinction between just cause and all-things-considered justification is made clear. On the face of it, the reference to "warrant" for coercive intervention is ambiguous between the two. But if this strategy is to improve on the one we just cast aside, it should be clear that it must be taken to concern the latter. Thus, the

\footnotetext{
${ }^{17}$ See Nussbaum 2002 for a critical examination of Rawls's program.
} 
claim can no longer be that only a certain (proper) subset of these rights can provide just cause for coercive intervention, for they all do. Rather, the claim is that only a certain (proper) subset is central enough to the lives of individual people to provide all-things-considered justification for coercive intervention. In all but a few select cases, then, coercive intervention will never be proportional to the injustice that it would seek to set right.

Considered as a proportionality claim, however, this conclusion has no sense until we specify a means of intervention. This is where the coercion continuum enters the picture. The question whether these means are each disproportionate as responses to violations of any these rights is not one which our theory should attempt to answer as such. Instead, responsible policy recommendations in this area can only be formed by taking into account a wide range of factors, such as the political motivation behind the injustice, the character of the regime that perpetrates it, the nature of the coercive means available, and the political window of opportunity that one operates within. Accordingly, prohibitive claims about proportionality cannot be issued without consideration of the particularities of the case. In particular, any attempt to bias the proportionality calculus by introducing a fixed parameter value for factors such as state sovereignty or communal autonomy will not work. To be sure, it would be a rare case where the integrity of their political institutions had no value whatsoever to the citizens living under them. But the actual value that these institutions have will vary with the injustices perpetrated under them. And, not least, the actual imposition caused by our coercive sanctions will vary with the means adopted. ${ }^{18}$ If the grounding claims of Global Justice theory are correct, as I believe they are, then we are all under a standing obligation to rectify injustices wherever they occur. It is a delicate question what means we may employ to discharge those obligations. But any good answer must carefully assess the situation at hand, and be prepared to take the full range of means into consideration. There is no credible grounds for a blanket dismissal of coercive force as a policy tool within Global Justice theory.

There remains the idea that Global Justice theory must be programmatically committed to advocating persuasion over coercion (Nussbaum 2011: 111-112). This seems right: the political

\footnotetext{
${ }^{18}$ It is important to remember that there will be significant variation in the degree of imposition on domestic political institutions even in the case of military intervention: some interventions may be aimed simply at halting violence in a particular region (which may not even be under de facto governmental control), while others will aim to overthrow the central government and reform the political and legal institutions that surround it (so-called "regime change").
} 
sensibilities that helped give birth to Global Justice theory are not frivolous, and should be honored. But even so, this idea is not without problems. Quite apart from the problem of determining when reasonable attempts at persuasion have run their course, ${ }^{19}$ there is a real danger of introducing a false dichotomy here. In many cases of real world politics, persuasion works not by the force of right reason alone, but can only operate against the background of an implied threat of coercion. Injustice is not, for the most part, borne from ignorance. It is naïve to suppose that state or regional leaders are simply unaware of what justice requires. Political repression is often sustained by corruption networks generating untold material gains for those who can hold on to power. In such cases, attempts at persuading political leaders to scale back on their abuse of power cannot avoid making appeal to their self-interest. But their perception of what is in their own interest in such cases is scarcely independent of their perception of the sorts of coercive options that third-parties are willing and able to put into action.

If this sounds like a concession to political realism, it need not be. In fact, it suggests a policy agenda that dovetails nicely with the grounding concerns of Global Justice theory. In particular, by bringing more and more countries into trade relations (on fair and equitable terms, it should go without saying), and by expanding cultural exchange more generally, we thereby also alter the incentive structure of the political leaders of these countries: they now have more to lose, and are thereby more susceptible to even the milder forms of coercion, such as trade embargoes and cultural boycotts. (For a favorably benign illustration, consider the crucial role played by the international sports boycott of cricket-crazy South Africa in turning white sentiment against the Apartheid regime.) The greater the integration, the greater their susceptibility to such means, and the less the probability that third-parties will ever be required to deploy them. Attempts at persuasion now find a footing which they did not previously. My point here can be seen to echo Kant, who argued that with the advent of trade, "states find themselves compelled to promote the noble cause of peace, though not exactly from motives of morality."20 So, while there is a clear sense in which we should favor persuasion over coercion, it is equally clear that the two must often go hand in hand in shaping a coherent policy.

\footnotetext{
${ }^{19}$ Analogous, of course, to problems relating to the last resort condition in Just War theory. On this, see Begby, Reichberg, and Syse 2012b: 335-336.

${ }^{20}$ Kant 1795, in Reichberg, Syse, and Begby 2006: 531.
} 


\section{Concluding remarks}

None of these arguments are meant to displace Global Justice theory as an account of the global reach of economic, social, and political rights. Far from it, my arguments are offered in the spirit of attempting to become clearer on the theoretical and practical implications of that account. I have argued that Global Justice theory must acknowledge a significant role for coercive force as a policy tool. In particular, any attempt to rein in on the evidently radical implications of the theory by imposing a high threshold for just cause can only damage its credibility. The correct line to adopt is that any systematic and sustained abuse of any right recognized under theory - be it freedom from enslavement, the right to political participation, or the freedom from harassment based on sexual orientation - provides just cause for intervention. Who is to intervene, if any, and by what means, if any, are further questions which can only be settled by recourse to context-specific information. My own account acknowledges that there will be many cases in which no agent possesses any justified means of intervention, even where there is just cause. This may seem to provide relief to the reluctant Global Justice theorist, whose fears of providing unwitting justification for neo-colonialism may after all be assuaged. So it may be. But on the other hand, this is hardly a cause for rejoice. Instead, it is testimony to the fact that ours is a world replete with moral tragedy, where even a moral agent armed with the best of intentions and efficient means at her disposal may find herself in a situation where her hands are tied, and there is no just way of carrying out justice.

\section{References:}

Ali, Mohamad M. and Iqbal H. Shah, 2000. "Sanctions and Childhood Mortality in Iraq." The Lancet 355(9218): 1851-1857.

Altman, Andrew, and Christopher Heath Wellman. 2009. A Liberal Theory of International Justice. Oxford University Press.

Begby, Endre. 2003. "Liberty, Statehood and Sovereignty: Walzer on Mill on Nonintervention." Journal of Military Ethics 2(1): 46-62.

Begby, Endre. 2010. "Rawlsian Compromises in Peacebuilding? Response to Agafonow." Public Reason 2(2): 52-60. 
Begby, Endre. 2012. "Collective Responsibility for Unjust Wars." Politics 32(2): 100-108.

Begby, Endre and J. Peter Burgess. 2009. "Human Security and Liberal Peace." Public Reason 1(1): 91-104.

Begby, Endre, Gregory M. Reichberg, and Henrik Syse. 2012a. "The Ethics of War. Part I: Historical Trends." Philosophy Compass 7(5): 316-327.

Begby, Endre, Gregory M. Reichberg, and Henrik Syse. 2012b. "The Ethics of War. Part II: Contemporary Authors and Issues." Philosophy Compass 7(5): 328-347.

Beitz, Charles. 1979. Political Theory and International Relations. Princeton, NJ: Princeton University Press.

Brock, Gillian. 2009. Global Justice: A Cosmopolitan Account. Oxford University Press.

Buchanan, Allen. 2006. "Taking the Human out of Human Rights." In R. Martin and D. Reidy, eds., Rawls's Law of Peoples: A Realistic Utopia? Malden, MA: Blackwell.

Caney, Simon. 2005. Justice Beyond Borders: A Global Political Theory. Oxford University Press.

Chatterjee, Deen K., and Don E. Scheid, eds. 2003. Ethics and Foreign Intervention. Cambridge University Press.

Cushman, Thomas, ed. 2005. A Matter of Principle: Humanitarian Arguments for the War in Iraq. Berkeley, CA: The University of California Press.

Global Policy Forum. 2002. Iraq Sanctions: Humanitarian Implications and Options for the Future. http://www.globalpolicy.org/component/content/article/170/41947.html

Hinsch, Wilfried, and Markus Stepanians. 2006. "Human Rights as Moral Claims Rights." In R. Martin and D. Reidy, eds., Rawls's Law of Peoples: A Realistic Utopia? Malden, MA: Blackwell.

International Commission on Intervention and State Sovereignty (ICISS). 2001. The Responsibility to Protect: Report of the International Commission on Intervention and State Sovereignty. Ottawa: The International Development Research Centre.

Kant, Immanuel. 1795. "Perpetual Peace.” Selections reprinted in G. Reichberg, H. Syse, and E. Begby, The Ethics of War: Classic and Contemporary Readings, Malden, MA: Blackwell, 2006: 518-538.

Luban, David. 1980a. "Just War and Human Rights." Philosophy \& Public Affairs 9 (2):160-181. 
Luban, David. 1980b. “The Romance of the Nation-State." Philosophy \& Public Affairs 9(4): 392-397.

Miller, Richard W. 2003. "Respectable Oppressors, Hypocritical Liberators: Morality, Intervention, and Reality." In D. K. Chatterjee and D. E. Scheid, eds., Ethics and Foreign Intervention, Cambridge University Press.

Nussbaum, Martha C. 2002. "Women and the Law of Peoples." Politics, Philosophy \& Economics 1(3): 283-306.

Nussbaum, Martha C. 2011. Creating Capabilities: The Human Development Approach. Cambridge, MA: Harvard University Press.

Pogge, Thomas. 1989. Realizing Rawls. Ithaca, NY: Cornell University Press.

Pogge, Thomas. 1998. “A Global Resources Dividend.” In D. Crocker and T. Linden, eds., Ethics of Consumption. The Good Life, Justice, and Global Stewardship, New York, Rowman and Littlefield.

Pogge, Thomas. 2005. "Recognized and Violated by International Law: the Human Rights of the Global Poor." Leiden Journal of International Law 18(4): 717-745.

Pogge, Thomas. 2009. "The Health Impact Fund: Boosting Pharmaceutical Innovation without Obstructing Free Access." Cambridge Quarterly of Healthcare Ethics 18(1): 78-86.

Rawls, John. 1999. The Law of Peoples, with "The Idea of Public Reason Revisited." Cambridge, MA: Harvard University Press.

Raz, Joseph. 2010. "Human Rights without Foundations." In S. Besson and J. Tasioulas, eds., The Philosophy of International Law, Oxford University Press.

Reichberg, Gregory M., Henrik Syse, and Endre Begby, eds. 2006. The Ethics of War: Classic and Contemporary Readings. Malden, MA: Blackwell.

Tan, Kok-Chor, 2010. "Enforcing Cosmopolitan Justice: The Problem of Intervention.” In R. Pierik and W. Werner, eds., Cosmopolitanism in Context, Cambridge University Press.

Tasioulas, John. 2009. “Are Human Rights Essentially Triggers for Intervention?” Philosophy Compass 4(6): 938-950. 
Walzer, Michael. 1977. Just and Unjust Wars: A Moral Argument with Historical Illustrations. $3^{\text {rd }}$ ed. New York: Basic Books, 2000.

Walzer, Michael. 1980. "The Moral Standing of States: A Response to Four Critics.” Ethics \& International Affairs 9(3): 209-229. 